\title{
The Classical Book Teaching and Learning Model for Children Boarding House
}

\author{
At Maktab Nubdzatul Bayan Al-Majidiyah Palduding Pagantenan Pamekasan Madura
}

\author{
Siswanto and Bunai \\ STAIN Pamekasan \\ Pamekasan, Indonesia \\ siswanto.abinaufal@gmail.com, abu.apk@gmail.com
}

\begin{abstract}
This research purposes to describe a background of choosing classical book teaching and learning model to children boarding house at Maktab Nubdzatul Bayan al-Majidiyah Palduding Pagantenan Pamekasan Madura, classical book teaching and learning model applied to santri, and the implication of teaching and learning model to santri's competency development. By using qualitative research approach and based on phenomenology, data collection technique using indepth interview, observation, and documentation, then this case obtain: Firstly, The classical book teaching and learning model choosing at this maktab is based on boarding house vision and caregiver efforts to realize santri's wishes on mastering religious science and classical book. The teaching and learning models choosing is considering santri's psychological condition who are mostly children's ages, guiders or mentors (musyrif) circumstances, and material depth learned; Secondly, The classical book teaching and learning is applied through accelerated teaching model using Nubdzatul Bayan classical book, created by this boarding house caregiver. This model focuses on mastery learning carried out through: 1) continuously interaction process; 2) learning method is adapted to the learning objective characteristics and it is carried out variably and focuses on practice or sorogan method; 3) the learning approach is oriented to optimize learning process and its learning outcomes. The approach is aimed to establishing santri's independence in learning, self-habituation, exemplary and individual approach. Thirdly, teaching and learning model that has been applied in this maktab has a big implication to santri's competence development, both on cognitive, affective and psikomotoric. They are able to understand and master the classical book in a short time. Besides that, they have additional competencies such as mastering Arabic and Mandarin, speaking ability (khitabah), and reviewing legal arguments by classical book comprehensively (bahts al-Masail).
\end{abstract}

Keywords-acceleration; children boarding house; classical book; santri; teaching and learning models

\section{INTRODUCTION}

The presence of boarding house as an educational institution is able to make an important and crucial contribution in the process of transmitting Islamic sciences, ulama's reproduction, knowledge maintenance and Islamic tradition, even the formation and expansion of Muslim societies [1].
Boarding house becomes a part of community infrastructure which overally has role to make people aware to have idealism, intellectual ability and good behavior to arrange and build nation character. Boarding house continually trying to shape people's behavior [2]. Boarding house becomes an ideal educational institution because it provides life skill laboratory which is very useful for santri's self-actualization [3]. Boarding house has become a center of excellence for human resources development that having a morality in social life [4].

On the other hand, boarding house is generally regarded as the Islam traditional basis, namely Islam which is still strongly bound by the thought of medieval clerics who proved firmly rooted in the Arab-Islamic culture of the classical period [5]. Because of its traditional nature, boarding school organization model almost entirely follow past tradition, both of curriculum and learning method. Some boarding house that exist today, it still maintain salafiyah pattern which considered sophisticated in facing external problems. Whereas it is required to do contextualization, without having to sacrifice original character [6].

The stigma that arises from teaching and learning in boarding house is traditional learning. Halaqah learning technique, sorogan and bandongan become a proof that teaching and learning in boarding house is still using conventional models. For some circles, this kind of teaching and learning model is no longer suitable to be applied in boarding house. They want modern learning models to be applied in boarding house. However, for others, the boarding house learning model should be maintained. They argue that it is precisely with this conventional model of teaching and learning that has generated a distinctive output and has contributed to the nation's development.

Given the diversity of santri's background and characteristic and demand to produce some graduates with capacities and capabilities that society need, so, learning need to be organized in an interactive, inspirational, fun, motivating santri to participate actively, and providing sufficient space for initiative, creativity and independence according to the talent, interest and physical and psychological development of santri. Thus, in designing the learning, it should place santri as a 
teaching and learning subject, so they have an optimal learning experience [7].

In its development, boarding house is not only devoted to adolescent and adult but also there are some boarding houses making innovations by specializing its santri to small children. One of them is Maktab Nubdzatul Bayan al-Majidiyah Palduding Pagantenan Pamekasan. When compared with existing boarding schools, especially in Madura, this boarding school has differences, including: Firstly, boarding house students consists of children aged 6-15 years who are psychologically different from adolescence and adulthood age. Secondly, the learning process is different from that experienced by adolescent or adult, so it required some methods and strategies that are varied enough in order that the goal set can be achieved. Thirdly, the characteristics of boarding house is different based on vision and mission one.

Based on research context above, the problem of this research is focused on: Firstly, the background of classical book teaching and learning model selection to children Boarding house at Maktab Nubdzatul Bayan al-Majidiyah Palduding Pagantenan Pamekasan; Secondly, the classical book teaching and learning Model applied to santri at Maktab Nubdzatul Bayan al-Majidiyah Palduding Pagantenan Pamekasan; and Thirdly, the implication of teaching and learning model on santri's competence development to children Boarding house at Maktab Nubdzatul Bayan al-Majidiyah Palduding Pagantenan Pamekasan.

For disclosing and describing the research focus, it requires a deep observation on a natural situation using a qualitative approach [8], so as to obtain a holistic, integral, and comprehensive picture of santri's learning model to children boarding house at Maktab Nubdzatul Bayan Al-Majidiyah Palduding Pagantenan Pamekasan.

This research type is categorized as case study, a depth research to the object (human, event, background, or document) in order to understand the interrelation between variables [9]. The theoretical orientation of this research is based on phenomenology, which the researcher tries to understand the meaning of events and their relation to the people in certain situation [10].

Data sources are obtained by observation, interview and documentation. While the data analysis using descriptiveexplorative analysis, involving 3 analysis components, namely: a) data reduction, b) data display, and c) conclusion. those three analysis components are interactive. Meanwhile, validity finding checking is done by extension of the researcher's presence, in-depth observation, triangulation, member checking, peer checking, and conformity tracking (referential adequacy).

\section{THE BACKGROUND OF CHOOSING ClASSICAL BOOK TEACHING AND LEARNING MODEL}

The choosing classical book teaching and learning model to santri at Maktab Nubdzatul Bayan, according to RKH. Abd. Mu'in Bayan is motivated by the effort from caretaker and founder of maktab and encouragement from all parties to realize needs and desires of the santri for mastering religious science and classical book. It requires serious attention because all santri have same passions and needs, to learn and increase knowledge. This Maktab provides an opportunity for all santri to develop their potential for gaining knowledge and provide a broad space for them to meet their needs.

Choosing of the teaching and learning model always notice satri's potentials. Teaching and learning is done by looking at all human potential, without neglecting other potential. Similarly, education must fill learners' needs in order to achieve maximum and best possible learning outcomes [11]. Maslow - in Boeree - reveals that individual behave an attempt to fill hierarchical needs, which include physiological needs, safety and security, loving needs and belonging needs, esteem needs, and self-actualization needs [12].

The choosing of teaching and learning model by the founder or caregiver solely to make santri having a qualified ability in mastering religious knowledge, especially classical book. The caregiver wants the santri are able to read and master classical book quickly in the not-too-distant future. It is done to realize the educational goals that have been set. In accordance with the vision and mission, this boarding house aims to build santri having ability in religious knowledge part evidenced by their ability in reading and mastering classical book as well as having a personality or noble character.

Every educational or teaching and learning process targets a certain goal, such as cognitive, affective or psychomotoric. This goal difference requires a teaching and learning model used [13]. In educational interaction, objectives have significance, because without purpose, activities that have been done will be less meaningful. It will even waste time and energy in vain [14]. In Gestalt theory, the teaching and learning process will be effective if learners know the goals they want to achieve. Teaching and learning occurs because learners have a certain expectation. Therefore, teachers should be aware of the goals as the direction of teaching activities and help learners to understand their goals [15].

According to one counselor, the consideration used to determine santri's teaching and learning model here is the material that will be taught to the santri. The teaching and learning materials that we give to santri gradually from one fan to another fan. To be able to read and master the classical book requires certain methods and strategies. And that is the emphasis of the counselors to choose teaching and learning model that will be applied to santri. In addition, the matter needs to know is the various santri's ability factors.

As known the majority of santri at Maktab Nubdzatul Bayan is still a child. It requires special attention in teaching and learning model choose. A varied teaching and learning model applied to santri, will make learning more natural and enjoyable.

Implementation of teaching and learning model in accordance with the existing mentorship abilities. The choosing of teaching and learning model considers the circumstances of the counselors. In term of teaching ability, mentors can be categorized as good in giving lesson to the santri. According to RKH. Abd. Mu'in Bayan Teachers or mentors can teach well because they prior to carrying out the learning process is given 
education and training about the learning model that will be applied first. Education and training are conducted routinely for existing teachers to provide the application of teaching and learning models and conditional or needs-based, especially for new teachers.

The existence of the consideration of teaching and learning model seection above is motivated by several rational reasons, namely: firstly, learning is a process that having goals. As simple as any teaching and learning process built by the teacher, the process is directed to achieve a goal. Secondly, teaching and learning is a process of cooperation. At least, teaching and learning process will involve teachers and learners. Thirdly, the teaching and learning process is a complex one. Teaching and learning is not just a matter of course, but a process of formation of learners' behavior. Fourthly, the teaching and learning process will be effective when utilizing various facilities and infrastructure available including utilizing various sources of learning [7].

\section{The Classical BooK TEACHING AND LEARNING ModEL APPLIED TO SANTRI}

The classical book teaching and learning model application is a necessity must be done by the counselor in teaching and learning activities. The quality of teaching and learning activities is very dependent on the teacher in the process of learning implementation. The duties of counselors are not merely teaching, but rather giving education to santri. They are encouraged to have individual awareness to learn. Learning at maktab is more emphasis on the process of interaction of all the situations existing around the santri. The learning model that has been implemented by the boarding house is continuous to achieve the educational goals set.

General Chairman of Maktab, Alamul Ulya argued that the continuity of the teaching and learning process at maktab looks at the activities under taken by santri, ranging from wake up around 3 hours to perform prayer tahajjud together. Similarly, at the time of study, they provide guidance and coaching to master the material being taught. Outside of study time, sometimes they continue in their respective room. So the interaction between mentor and santri occurs continuously. The mentors are placed in a room with the santri. They are given the responsibility to guide or coach about 10 santri. Their duties range from teaching, accompanying discussion, organizing lifestyle, and so on.

According to Gestalt's theory, learning is concerned with the whole individual and arises from his mature interaction with his environment. Through this interaction, then formed forms of perception, imagination and new views. All of them, together form the understanding or insight, which works as long as the individual solves the problem. Nevertheless the insight will give a function only if there is perception [16].

The teaching and learning models applied by teachers to one another are essentially same. Like al-Tanzil and I'dad program, determined learning and teaching steps, what needs to be achieved, where the target to be achieved according to time set, criteria of graduation or rising juz, and so on. Similarly, for example Nubzatul Bayan program, it has also determined the target achievement, passing criteria and increase juz and mastery and reading comprehension of the book, and others.

RKH. Abd. Mu'in Bayan affirms that they refer to the teaching guidelines prepared at each stage or level. These guidelines contain a grid or reference for the implementation of the lesson including methods to be used, the execution of the exam, the teaching and learning materials, and the things to be achieved in the learning at each level. The similarity of the application of this teaching and learning model is expected to provide maximum results and make it easier to conduct an evaluation on every process in progress. Determination of this model is intended to provide the signs of the implementation of learning to take place effectively. The teaching and learning objectives will be more easily achieved.

All the guidelines for the implementation of the teaching and learning model have been prepared completely based on the existing program and determined the target time that must be undertaken by santri including:

A. The Acceleration Program for Reading and Writing the Qur'an (al-Tanzil and I'dad) is organized as follows:

- Juz I - VI is determined for 270 days (9 months) which is held each juz for 45 days;

- Reading and Writing the Qur'an and Latin Deepening for 210 days (7 months)

- I'dad (pre-Nubdzah) for 90 days (3 months).

\section{B. Classical Book Reading Acceleration Program (Nubdzatul} Bayan) is organized as follows:

- Volume I - V is held for 125 days (4 months 15 days) with details of each volume for 25 days

- Takmiliyah for 30 days (1 month)

- Practice 1, it is applied to santri graduated from Takmilah to practice test and still apply in volumes as applicable to the previous volume with the same time target as takmilah, it is 30 days.

- Practice 2, it is applied to santri who have done practice test and passed the test. In this practice, no binding system applies.

\section{Fathul Qarib Understanding Acceleration Program (post Nubdzah)}

For santri who have been graduated from Nubdzatul Bayan program or have joined a graduation, they will be educated intensively in understanding the content of Fath al-Qarib for 3 months and then transferred to Takhassus program.

\section{The Acceleration of Scripture Understanding Program (Takhassus)}

In this program the time target is set according to the specified fan, for example Faraidl 1 fan (Khulashah al-Kalam) is specified from Furudl to al-Hajbu for 10 days, while from Jadd wa al-Ikhwah up to 20 days, and continued on to the next fan [17]. 
Meanwhile, the stage applied in the teaching and learning process are done through several steps that have been contained in the learning guidelines, namely: the first, iftitah (opening), includes the intention to learn santri for expecting ridla Allah, reading al-Fatihah and praying before starting learning and reading of learned nazham; the Second, pre-test, it was done before the subject matter is given to know santri's understanding on previous material. The goal is to remember previous lesson and write some examples and ask the material and the theorem without looking at the book; the Third, core activities include material presentation, examples and explanations as well as previous lesson demonstrations in the presence of other mentor and santri; the Fourth, Post-tes, asking back the taught material and santri's responds without looking at the book. The Fifth, ikhtitam (closing), it was done by reading argument nazham that have been studied and then praying together [18].

The similarity of this model does not close the chances for teacher or mentor to do improvisation in developing learning. In the sense, they can develop such learning by not ignoring the predefined teaching and learning model. Determination of the similarity of this model is expected solely to facilitate in assessing the results of learning santri in accordance with the time already determined.

In general, the methods application focuses more on practicing or sorogan method, each santri is given the opportunity to "deposit" the material that has been studied to the mentors. And Other methods are lecturing method, practice, demonstration, memorizing, sorogan, and so on. With the lecturing method, the teacher explained the material contained in the book along with an explanation of sentence examples and their arguments. In practicing method, emphasized on santri's mastery in determining sentence, which is done by the teacher orally. This practice can be define sentences, practices to give meaning, practice to give explanation of books read and other exercises. Nevertheless, the teacher can creat to make learning better. But importantly, the goal to be achieved becomes the main key of learning. Implementation of teaching and learning method aimed at acceleration santri to be able to master the subject matter. Every santri required to master material fully that is taught or mastery learning.

Mastery learning is a learning approach model whose success indicator is seen from the number of subject matter that has been mastered by learners either cognitively, effectively, or psychomotor. With the model of mastery learning, the knowledge of santri on various knowledge can be optimized and hence they have many knowledges and on each level, and ready to face the test which generally put forward on cognitive aspects [13].

In the learning guide of Maktab Nubdzatul Bayan described some teaching and learning methods that should be used by the teachers or mentors in the learning process, namely:

- Taqti 'method, introducing the sentence, sighat, position and so on that relate to some sentences in classical book by introducing one by one, sentence by sentence so that santri can understand the sentence read and can determine the position of its sentence.
- Deposit Method, santri deposit back the classical book that has been introduced 'to the mentor. The purpose of this method is to increase santri's mastery in reading classical book. Each santri is required to deposit to read the classical book or memorize the material that has been taught by the mentor turnly.

- Tadarus method, reading the classical book grouply leading by a mentor as a regulator and control activities. This method is the same as the tadarus of the Qur'an, the difference is the mentor is free to ask the sentence or position to the santri, even when the mentor finds the wrong reading, he is not allowed to correct the wrong reading, but he should ask the reason of the reading.

- Demonstration Method, the method with demonstrating or inquiring in detail about sentences in the classical book, either by joint or direct question individually [19].

The teaching and learning model implementation that has been done, has implications for the formation of reading culture and learning culture among santri. They are not entirely dependent on teacher attendance to learn, but they can increase knowledge from shared discussions and deliberations.

The process of teaching and learning implementation has taken place in accordance with the criteria of PAIKEM, which is held interactively, inspiration, fun, challenging, motivate students to participate actively, and provide sufficient space for initiative, creativity, and independence according to the talents, interests and physical and psychological development of students.

Thus, in the teaching and learning implementation, teachers place student as subject learning, so they have an optimal learning experience [7]. The progress of learning is largely determined by student's behavior changes that can be observed and able to do something that previously could not be resolved [20]. This Maktab has collaborated various methods in teaching and learning with a principle that in the learning process must occur student engagement, fun for students and can provide great benefits for them [21].

Given the learning model in maktab is focused on the demands of full mastery of teaching materials in a fast time, then the mentors is also required to use individual approach to each santri. This approach is done to provide assistance to the students in dealing with problems in the teaching and learning process. The individual approach is based on the assumption that learners have different background in term of intelligence, talent, inclination, motivation, and so on. The individualistic differences of learners provide insight to the teacher that the learning model should pay attention to the difference of learners [13].

\section{Classical Book Teaching AND Learning Model IMPLICATION ON SANTRI's COMPETENCE DEVELOPMENT}

The Classical book teaching and learning model applied in this maktab gives an enormous impact and motivation to learn santri in developing their competence. Most santri can complete their learning targets according to the time specified. With the application of learning model that focuses on 
students, it gives a positive impact on their sincerity in mastering every subject matter taught. They were able to understand the classical book in a short amount of time. Usually understanding it takes a long time, but with the model application and learning method as applied in this maktab, able to provide convenience for santri in mastering classical book.

The teaching and learning result achievement as described above is closely related to the standard of competence or priority capabilities that are prioritized and established by this maktab. The competency standards are arranged in stages based on educational program that is implemented with the respective implementation time which has also been established. Generally, the standard of competence or the main ability emphasizes the understanding or mastery and sharpening of religious material, with regard to the age level of santri.

In the educational guidance of Maktab Nubdzatul Bayan alMajidiyah, the standard of competence or priority that is a priority for santri has been formulated clearly as follows:

- al-Tanzil program (Acceleration of Reading and Writing Qur'an and Latin) is directed for one ability to read and write al-Qur'an.

- I'dad program (especially for new santri who did not pass in Nubdzatul Bayan program) is directed for preparing on Nubdzah program. The expected ability is reading and writing al-Qur'an and mastering tajwid science.

- Nubdzatul Bayan program (Acceleration of Reading classical Book) is directed for mastering qawa'id science which has been determined on Nubdzatul Bayan. They must also particularly be able to read Fath al-Qarib in preparation for joining Takhassus program.

- Takhassus Program (Acceleration of classical Book). Directed for deepening classical book mastery according to their respective fan. In this program emphasizes on the independence of santri in taking reference of contemporary religious issues (al-masail al-diniyyah al-waqi'iyyah) [19].

In boarding house is not limited as in educational institutions that use classical system. Generally, the increase in the level of santri or standard of santri's competence is based on the content of certain subjects marked by graduation and replacement of the book he or she studies. If a santri has mastered a book that has been tested by his caretaker, then he moved to another book higher level [22].

In addition to the santri's main competencies or abilities have been determined above, the santri are also given extracurricular subject such as learning foreign languages both Arabic and Mandarin, lecturing exercises (khitabah), extra study of classical book, and giving guidance and counseling services for santri. This extracurricular subject is considered important given that applied sciences are indispensable to them in life outside of boarding house. Especially as today, the development of science increasingly rapidly, requires us to master various skills in order to compensate that development.
The teaching and learning model that has been applied in Maktab Nubdzatul Bayan contributes to the development of accelerated learning in traditional boarding house as has been widely applied in various modern educational institutions. Accelerated learning model in maktab is directed at the ability to read and understand classical book with emphasis on mastery learning (complete learning). This accelerated learning has succeeded in improving reading and comprehension of santri and their achievement in a rapid manner. Learning centers on activities designed in a much shorter time than other learning.

Through this accelerated learning, maktab is able to grow santri's learning culture so that they can be fully involved, accelerate and improve result learning, accelerate the learning process, build effective learning community and create a more communicative learning environment.

\section{CONCLUSION}

Based on the description of the research results and discussion above, the author can conclude as follows:

- The teaching and learning Model Selection of Santri Maktab Nubdzatul Bayan al-Majidiyah Palduding Pagantenan Pamekasan is based on caretaker's and founder's of maktab efforts to realize the needs and desires in mastering religious science and classical book. Learning model selection also consider several things, namely: a) the psychological condition of santri that the majority of children age; b) the circumstances of the mentors who can be categorized as good in giving lessons to the santri; and c) the depth and breadth of the material being taught.

- The teaching and learning model at Maktab Nubdzatul Bayan al-Majidiyah Palduding Pagantenan Pamekasan applies acceleration model with emphasis on mastery learning. In applying this model, maktab has implemented: a) interaction process continuously; b) The teaching and learning method is adapted to the characteristics of the learning objectives and carried out variably, although more emphasis on the method of practice or sorogan method; c) The teaching and learning process is emphasized on active learning strategies, such as discussion method, question and answer and so on; d) The approach is oriented to optimize the learning process while optimizing the result learning. The approach that leads to independence in learning, familiarization, exemplary and individual approach.

- The teaching and learning model that has been applied in this maktab give impact and big learning motivation to santri's seriousness in developing their competences. Most santri can complete their learning targets according to the time specified. They were able to understand the classical book in a short amount of time. Standards of competence or primary ability emphasize the understanding or mastery and sharpening of religious material, with regard to the age level of santri. In addition, additional competencies or abilities are 
Foreign language learning both Arabic and Mandarin, lecturing exercises (khitabah), extra study of classical book, and giving guidance and counseling services for santri.

\section{REFERENCES}

[1] A. Azra, Konteks Berteologi di Indonesia, Pengalaman Islam. Jakarta: Paramadina, 1999, hlm. 184-185.

[2] Suwendi. Sejarah dan Pemikiran Pendidikan Islam. Jakarta: Raja Grafindo Persada, 2004.

[3] M. Nafi', Dian et al., Praksis Pembelajaran Boarding house. Yogyakarta: Institute of Training and Development (ITD), 2007.

[4] N. Syam. Transisi Pembaruan, Dialektika Islam, Politik dan Pendidikan. Waru: LEPKISS, 2008.

[5] M. Arif, Pendidikan Islam Transformatif. Yogyakarta: LKiS, 2008.

[6] A. Fajar, Malik. Reorientasi Pendidikan Islam. Jakarta: Fajar Dunia, 1999.

[7] W. Sanjaya, Perencanaan dan Desain Sistem Pembelajaran. Jakarta: Kencana, 2009.

[8] R.C. Bogdan and S.J. Taylor, Introduction to Qualitative Research Methods: A Phenomenological Approach to the Social Sciences. New York: John Wiley and Sons, Inc., 1985.

[9] S. Arikunto, Prosedur Penelitian Suatu Pendekatan Praktek. Jakarta: Rineka Cipta, 1993.
[10] L.J. Moleong, Metodologi Penelitian Kualitatif. Bandung: Remaja Rosda Karya, 2009.

[11] Baharuddin dan M. Makin, Manajemen Pendidikan Islam, Transformasi Menuju Sekolah/Madrasah Unggul. Malang: UIN Maliki Press, 2010.

[12] C.G. Boeree, Personality Theory, terj. Yogyakarta: Prismasopie, 2006.

[13] A. Nata, Perspektif Islam tentang Strategi Pembelajaran. Jakarta: Kencana, 2009.

[14] S.B. Djamarah, Guru dan Anak Didik dalam Interaksi Edukatif. Jakarta: Rineka Cipta, 2000.

[15] Rusman. Model-model Pembelajaran, Mengembangkan Profesionalisme Guru. Jakarta: Rajawali Press, 2011.

[16] T.N. Hidayati, "Implementasi Teori Belajar Gestalt pada Proses Pembelajaran," Jurnal FALASIFA, vol. 2, no. 1.

[17] The Guidelines of The teaching and Learning at Maktab Nubdzatul Bayan al-Majidiyah Palduding Pagantenan Pamekasan.

[18] The General Direction of The Teaching and Learning at Maktab Nubdzatul Bayan al-Majidiyah Palduding Pagantenan Pamekasan.

[19] Tim Penyusun, Konsep Pendidikan Maktab Nubdzatul Bayan alMajidiyah. Pamekasan: t.p., $1433 \mathrm{H}$.

[20] B.R. Hergenhahn and H.O. Matthew, An Introduction to Theories of Learning. New Jersey: Printice Hall, 1997.

[21] A. Maimun dan A.Z. Fitri, Madrasah Unggulan, Lembaga Pendidikan Alternatif di Era Kompetitif. Malang: UIN Maliki Press, 2010.

[22] M. Sulthon dan M. Khusnuridlo, Manajemen Pondok Boarding house dalam Perspektif Global. Yogyakarta: LaksBang Pressindo, 2006. 